\title{
Role of Self Concept on Adjustment among Middle Aged Women
}

\author{
Pragati Dixit*
}

\section{ABSTRACT:}

The purpose of the study was to determine the role of self concept on adjustment among middle aged women. Self concept is the way people think about themselves including their abilities, physical features, goals and social roles. Adjustment refers to the process by which an individual makes an adequate relationship with his environment and satisfies his needs. M.R. Rastogi's Self Concept Scale and Global Adjustment Inventory of Psy-com services was used for obtaining data. The sample consisted of 120 married women with age range 30- 45 years selected by means of purposive random technique of sampling. Regression analysis and t-test was used to analyze data. Results indicated that self concept influences adjustment of women positively.

Keywords: Self concept, Adjustment

\section{INTRODUCTION}

The concept of self is probably one of the most admired ideas in psychological and educational literature among the various popular concepts which is considered as a key to success. It is important to mention that self-concept is a central theme around which a large number of the major aspects of personality are organized. Self-concept is individuals' perception of their abilities, behavior and personality on the whole. It refers to an individual's beliefs and understanding about himself that are developed from the experiences that the person gains through the interaction with others in the society and are concerned with personality traits, abilities, physical features, values, goals and social roles. If people have a positive attitude towards own self and confidence in them then they may get success in every sphere of life. Selfconcept is the way people think about themselves. It is unique, dynamic, and always evolving. This mental image of oneself influences a person's identity, self-esteem, body image, and role in society. As a global understanding of oneself, self concept shapes and defines who we are, the decisions we make, and the relationships we form. It is perhaps the basis for all motivated behavior (Franken, 1994).

Raimy (1943) was the first person who defined the self-concept as " the more or less organized perceptual object resulting from present and past self observation... (i.e.,) what a person believes about him. The self-concept is the map which each person consults in order to understand him, especially during moment of crises or choice".

\footnotetext{
* Research Scholar, Department of Psychology, Aligarh Muslim University, Aligarh
} 
Some researchers described self-concept as an organized collection of beliefs and selfperceptions about oneself, including one's attitudes, knowledge and feelings regarding abilities, appearance and social relationships. The self is a framework that determines how we process information about ourselves, including our motives, emotional status, self-evaluations, abilities and much else besides (Klein, Loftus \& Burton, 1989; Van Hook \& Higging 1988). Self-concept is also defined by Purkey (1988) as the sum of a complex, organized, and dynamic system of learned beliefs, attitudes and opinions that each person holds to be true about his or her personal existence.

It can be better understand in the words of Thompson (2003) "self concept is a multidimensional construct, including the dimension of self worth. Self-concept includes an individual's overall perception of their psychological and physiological being, where as self-esteem is the judgment of worth an individual assigns to his or herself."

Thus, there are various views regarding self concept but a general agreement is made that self concept is the knowledge of a person about his own abilities, personality characteristics, social relationships and their role and position in the society. Self concept can either be positive (high) or negative (low). Positive or high self concept is important because it leads to sense of self worth, self- confidence, self respect, positive self evaluation, self esteem and self acceptance (Arthur, 1992). High self concept enables an individual to execute at superior level and utilize the learning experiences in the most favorable manner. On the other hand, low self-concept leads to frustration and involves in self-hatred (Lebar, 1999). Different views are proposed besides these two dimensions regarding whether self-concept reflects multiple or a single unity structure (Campbell et al., 2003). A common idea is that self is a multidimensional construct which consists of very different cognitive and affective components. On the other hand, consent has been reached that self is a unitary structure which depicts global ideas such as self-esteem and self-clarity (Nowak et al., 2000; Rogers, Kuiper \& Kirker, 1977).

Self-concept encompasses three major qualities as suggested by Purkey (1988) that it is

- learned,

- organized,

- dynamic

Self concept is a psychological construct that affects thoughts, emotions and also other behaiviours (Byrne, 1996; Harter, 1990; Marsh, 1990). Thus, it becomes essential to understand about women's concept of self as Messias et al. (1997) stated that occupying multiple roles is thought to increase the women's chances to learn, to develop self-efficacy and self-esteem, to build social network and open access to informational, instrumental and emotional support, and to buffer life's stresses and strains. The importance of self-concept stems from its influence over the quality of a person's behavior and his/her method of adjustment to life and situation. It determines an individual's adjustment in all the spheres of life as if the person is having positive view of himself then it will be easy for him to adjust in a new environment. Ybrandt (2007) explained that a positive self concept is the most important factor for adjustment and as a 
safeguard against typical problems behaviours (internalized and externalized). Thus study of adjustment also becomes essential while looking for self concept of women.

Adjustment refers to the extent to which an object fits the purpose for which it is intended. In simple words it is a process that makes a balance between the demands of the environment and needs and interests of an individual. It is an active process by which the daily programs run smoothly without being affected. It occurs as the individual lives in his family situation, advances educationally, pursues vocational outlets, and engages in social relationships. His adjustment is helped as he acquires new experiences, accepts ideas and behaviour with which he may not agree, conforms to the ways of the members of the group or to the mores of society and strives to attain self realization. Adjustment is a static equilibrium between an organism and its physical and social surroundings in which there is no stimulus change evoking a response. Further no need remains unsatisfied and all the continuative functions of the organism are proceeding normally. In broader sense adjustment refers to the psychological processes through which human beings manage or cope with the demands, challenges, and frustrations of everyday life.

The extent to which an individual is able to achieve successful life adjustment prominently depends on the environmental stimuli to which he is successively exposed during his life span, especially during his childhood and adolescent years and his inherited and acquired power to make whatever changes within himself that shall serve as the bases of constructive thinking, feeling and doing. Poor environmental conditions and/ or deficient potentially are more than likely to encourage the development of maladjustments that can be harmful both to the individual himself and to those other persons whose lives are affected by his demonstrated attitudes and behaviour.

Thus, it can be said that adjustment is a continuous process by which an individual makes an adequate relation with his/her environment and fulfill his basic needs in a reasonably satisfied manner. In other words, it is the process by which a person varies his/her behaviour to produce a more harmonious relationship between him and the environment in which he/she lives. It has also been defined as the individual's successful adaptation to and interaction with his environment.

An individual's degree of successful adjustment in various spheres is perhaps strongly related to his/her past experiences, environmental influences and personal strengths. An individual hold the power to select, and to apply to himself the environmental elements and the experiences that may seem to him to be best suited to satisfactory adjustment. At the same time, however, the operation in a person's life of scientifically evolved principles of cause and effect cannot be disregarded.

Adjustment refers to the individual's behaviour delaying with or mastering demands that are made upon him by his/her environment. It is emphasized that adjustment is a learned behaviour, not an innate quality and is a continuous and indispensible process which is necessarily determined by the norms of the society and the environment with which the person is associated. 
As it is known that adjustment is a process of continuous interaction, since both the organism and its environment is not static. It is a dynamic aspect concerning to any individual as the environment differs adjustment also differs. Adjustment may be viewed from two dimensions. First, adjustment may be viewed as an achievement or how well a person handles his conflicts and overcomes the resulting tension. Second, adjustment may be looked upon as a process or how a person adjusts to his conflicts.

Bala and Laxmi (1995) reported that perceived self concept as well as social self concept was positively correlated with marital adjustment for both employed and unemployed women.

Dixit (2013) conducted a study on a sample of 400 women (200 housewives and 200 career women) and found a positive relationship between self concept and adjustment. It was also reported that worthiness, abilities, emotional maturity, health and sex appropriateness and present, past and future are the significant predictors of adjustment for housewives as well as for career women.

\section{PURPOSE OF THE STUDY:}

In recent years, many studies have been conducted on self concept and adjustment but most of them are done on adolescents. However a few studies have been done in the context of women's self concept and its influence upon adjustment. Therefore present investigator attempts to study self concept of women and its effect on adjustment.

\section{OBJECTIVES:}

- To assess self concept and adjustment of women,

- To determine the influence of self concept lon adjustment of women,

- To determine the weather levels of self concept affect adjustment of women.

\section{HYPOTHESES:}

- Self concept will predict adjustment of women,

- There will be no significant difference between adjustments of women having high and low self concept.

\section{METHOD:}

\section{Participants:}

The participants of the present study consisted of 120 married women age ranges from $30-45$ years. The women included in the study belonged to urban background. The participants were selected through purposive random sampling technique from Aligarh city. 


\section{Tools:}

Self Concept Scale:

In the present study Self Concept Scale developed by Rastogi (1979) was used for obtaining the information regarding the concept of 'Self' of women. This scale seems to be the most suitable tool for measuring self concept in the present study as it was meant for Indian adult population. It is a 51 item scale scoring on five point rating scale ranging from 'strongly agree' to 'strongly disagree' with possible score of 51 to 255 . This scale consists of ten constructs covering three dimensions of Self-concept i.e., Perceptual, Conceptual and the Attitudinal dimensions. Thus, the ten constructs are - Health, Abilities, Self-Confidence, Self-Acceptance, Worthiness, Present, Past and Future, and Belief and Convictions, Shame and Guilt, Sociability and Emotional Maturity. There were 22 positive statements and 27 negative statements and each dimension consists of both types of statements. Positive statements were scored as 5,4,3,2,1 whereas negative statements were scored as 1,2,3,4,5. The greater score indicates, better self-concept of an individual. The reliability of the scale by split half method was found to be 0.87 .

\section{Adjustment scale:}

The Global Adjustment Scale 'Adult Form' was used to measure the adjustment of women. This scale was developed by Psy-com services in 1994. This scale measures the level of adjustment in six areas named family, health, emotional, occupation, sexual and social. Lower scores on scale indicate better adjustment in all areas. The description of its dimensions are as under:

Family: This dimension includes statements regarding relationships with spouse, children, freedom and cohesion in the family.

Health: It is related to the physical function of the body.

Emotions: It includes the statements regarding maturity and sensitivity.

Occupation: This dimension mainly centered on the feeling of job satisfaction and job involvement.

Sex: It includes sex related behavior i.e., sex related knowledge, anxiety, myths.

Social: This aspect measures hostility/submissiveness in behavior, acquaintances outside home and how much trust the person has on people around him.

Every area had 20 items to be rated as yes, no or sometimes. There were also some negative statements that were scored as $0,2,1$. The score on the scale can range from 0 to 240. 
The reliability through split half method for emotional, family, health, occupation, sexual and social is $0.76,0.66,0.69,0.68,0.79$ and 0.73 respectively. The factorial validity coefficient for emotional adjustment is .70 , family adjustment .58, health adjustment .65 , occupational adjustment .61, sexual adjustment .72 and for social adjustment is .65 .

\section{Procedure:}

The researcher contacted to all the participants individually. The women were contacted either at their work place or at home. The questionnaire was given to the respondents after establishing good rapport with them and requested to fill up the questionnaires. The participants were asked to fill-up all the statements by following the instructions given in each of the questionnaire. The subjects took 15-20 minutes in giving their response. The subjects were told to mention their age, income and education. In the last the researcher appreciated for their co-operation and help.

\section{Statistical Analysis:}

In view of the nature of research investigation and the hypotheses of the study $\backslash$ Regression Analysis was used to ascertain the influence of self concept on adjustment. Regression Analysis by adopting Stepwise method was found most appropriate in analyzing the data. Further, high, moderate and low groups were formed on the basis of quartile deviation of the raw scores of self concept scale to ascertain whether level of self concept affect adjustment of women. Analyses were done using 16.0 version SPSS (Statistical Package for Social Sciences), which yielded results in different steps. The obtained results are discussed in later pages.

\section{RESULTS AND DISCUSSION:}

Table -1, Table showing dimensions of self concept that predict adjustment of women

\begin{tabular}{|c|c|c|c|c|c|c|}
\hline Model & $\mathbf{R}$ & R Square & $\begin{array}{c}\text { R Square } \\
\text { change }\end{array}$ & Beta & $\mathbf{t}$ & Significance \\
\hline 1 & $.362^{\mathrm{a}}$ & .131 & .131 & .298 & 3.54 & .001 \\
2 & $.457^{\mathrm{b}}$ & .209 & .077 & .285 & 3.39 & .001 \\
\hline
\end{tabular}

a. Predictors: (Constant), present, past, future

b. Predictors: (Constant), Present, past, future, self acceptance 
Above table highlights the dimensions of self concept which emerged as significant predictors of adjustment. Present, past, future and self acceptance found to be significant predictors of adjustment among women. Multiple correlations was found to be .457 for present, past, future and self acceptance. Further R square was shown that represents the contribution of the predictor variable. The $\mathrm{R}$ square change which was considered as the actual contribution of predictors to the criterion variable was found to be .131 for present, past, future and .077 for self acceptance. The beta value which indicates the relationship between the predictors and dependant variable showed positive relation among all the predictors and dependent variable.

Present, past and future was predictor of adjustment that should be considered as the t-value (3.54) was also found significant. Present, past and future refers to the coordination between the past and present events and their influence on the future events also. The beta value that was found positively related with adjustment also revealed that the adjustment increases when the past events do not affect present and future events.

Self acceptance was found to be other predictor of adjustment among women. Self acceptance refers to approve yourself in the way you feel about yourself. There is no conflict between the real and ideal self of an individual. The t-value (3.39) was found to be statistically significant which showed that women who perceive themselves as they are and not wanted to be like others, they will be better adjusted as it has been observed that huge discrepancy between the perceived self and the real self or the ideal self will probably lead to unhappiness, poor adjustment and further mental health problems.

Table -2, Table showing the comparison of different adjustment of high, moderate and low self concept groups

\begin{tabular}{|c|c|c|c|c|}
\hline $\begin{array}{c}\text { Level of self } \\
\text { concept }\end{array}$ & N & Mean & S.D. & t \\
\hline High & 31 & 62.67 & 22.31 & $5.18^{*}$ \\
\hline Moderate & 60 & 89.10 & 23.37 & $2.93^{* *}$ \\
\hline Low & 29 & 105.34 & 26.58 & $6.75^{*}$ \\
\hline
\end{tabular}

*.01 level, **.05 level

Further, the sample was divided into high, moderate and low groups on the basis of quartile deviation of raw scores obtained on self concept scale to ascertain whether levels of self concept affect adjustment of women as shown in table 2. It is evident (table 2) that the mean 
score 62.67 of women who were having high level of self concept found to be better adjusted as compared with moderate (89.10) and lower (105.34) self concept group. The women who have lower self concept were found to be less adjusted as compared with the other two groups as lower scores on this adjustment scale are the indicator of better adjustment in each of the dimension. To examine the significance of the difference between two groups, t-value was calculated and it was observed that high and moderate group differed significantly in terms of their adjustment as the t-value (5.18) is also statistically significant. The t-value (2.93) women having of moderate and low level of self concept was also found to be significant and similarly the t-value (6.75) between women having high and low level of self concept was also found to be significant. It can be said on the basis of the results that level of self concept affects women's adjustment as all the three groups differed significantly. Thus, it may be said that positive self concept seems to be essential for different types of adjustment as it was observed in some of the researches that persistent low self-concept has been linked to depression, adjustment problems, suicide and alcohol use, etc. (Harter \& Monsour,1992; Harter \& Marold,1994; Swain \& Wayman ,2004). Sharpley and Khan (1980) reported a high positive relationship between marital adjustment and self concept.

The low self concept group was low on adjustment may be attributed to the symptoms that a person develops such as lack of self confidence, feeling of worthlessness, does not believe on his abilities which all the essential qualities for making adjustments in every sphere of life. It seems from the above results that women who have lower level of self concept feel inferior to others which seem to be an obstacle in achieving good adjustment. On the contrary high level of self concept is beneficial for everyone as it increases self confidence, feeling of worthiness, self acceptance, believe in own abilities which all contributed to better adjustment as compared with low and moderate level of self concept.

\section{CONCLUSION:}

The present study revealed that present, past, future and self acceptance are the significant dimensions of self concept that predicts adjustment of women. It was also found that level of self concept affects adjustment of women. The women having high level of self concept were found to be better adjusted as compared to women having low self concept. It can be concluded that self concept is an important determinant of adjustment among women.

\section{REFERENCES}

1. Arthur D. (1992). Measuring the professional self concept of nurses: A critical review. Journal of Advanced Nursing, 17 (6), 712-719.

2. Bala, M. \& Laxmi (1995). Relationship of self concept with marital adjustment in educated employed and educated unemployed women. Indian Journal of Applied Psychology, 32 (1\&2), 40-44. 
3. Byrne, B.M. (1996). Measuring the self concept across the life span: Issues and instrumentation. Washington, DC : American Psychological Association.

4. Campbell, J.D., Assanand, S., \& De Paula, A. (2003). The structure of the self-concept and its relation to psychological adjustment. Journal of Personality, 71 (1), 115-140.

5. Dixit, P. (2013). A study of the level of anxiety, self concept, adjustment and mental health problems of housewives and career women. Ph. D Thesis, Aligarh Muslim University, Aligarh.

6. Franken, R. (1994). Human motivation ( $3^{\text {rd }}$ ed.). Pacific Grove, CA: Brooks/Cole Publishing Co.

7. Harter, S. (1990). Causes, correlates and the functional roles global self worth. A life span perspective. In R.J. Sternberg \& J. Kolligian (Eds.), Competence Considered. New Haven, CT: Yale University Press.

8. Harter, S., \& Marold, D.B. (1994). Psychological risk factors contributing to adolescent suicide ideation. In G. Noam \& S. Borst (Eds.), Child and adolescent suicide (pp. 71-91). San Francisco: Jossey-Bass.

9. Harter, S., \& Monsour, A. (1992). Developmental analysis of conflict caused by opposing self-attributes in the adolescent self-portrait. Developmental Psychology, 28, 251-260.

10. Klein, S.B., Loftus, J., \& Burton, H.A. (1989). Two self reference effects: The importance of distinguishing between self descriptiveness judgments and autobiographical retrieval in self referent encoding. Journal of Personality and Social Psychology, 56 (6), 853-865.

11. Marsh, H.W. (1990). A multidimensional, hierarchical model of self-concept: Theoretical and empirical justification. Educational Psychology Review, 2, 77-122.

12. Messias, D.K., Im, E., Page, A., Regev, H., Spiers, J., Yoder, L., \& Melesis, A.I. (1997). Defining and redefining work: implications for women's health. Gender and Society, 11, 296.

13. Mohd Salleh Lebar. (1999). Memahami Psikologi. Selangor: Thinker's Library Sdn. Bhd. Retrieved on 08 June 2012 from www.management.utm.

14. Nowak, A., Vallacher, R.R., Tesser, A., \& Borkowski, W. (2000). Society of self: The emergence of collective properties in self-structure. Psychological Review, 107 (1), 3961.

15. Purkey, W. (1988). An overview of self-concept theory for counselors. Retrieved on 24 November, 2012 from http://www.eric.ed.gov

16. Raimy, V.C. (1943). The self concept as a factor in counseling and personality organization. Unpublished Doctoral Dissertation, Ohio State University.

17. Rogers, T.B., Kuiper, N.A., \& Kirker, W.S. (1977). Self-reference and the encoding of personal information. Journal of Personality and Social Psychology, 35 (9), 677-688 
18. Sharpley, C.F. \& Khan, J.A. (1980). Self concept, values-systems and marital adjustment: Some implications for marriage counselors. International Journal for the Advancement of Counselling, 3 (2), 137-145.

19. Swain, R.C., \& Wayman, J.C. (2004). Multidimensional self-esteem and alcohol use among Mexican American and White non-Latino adolescents: Concurrent and prospective effects. American Journal of Orthopsychiatry, 74, 559-570.

20. Thompson, L.L. (2003). The effect of body image on Self Esteem across ethnicity. Undergraduate Journal of Psychology, 26, 249-269.

21. Van Hook, E., \& Higgins, E.T. (1988). Self related problems beyond the self concept: Motivational consequences of discrepant self guides. Journal of Personality and Social Psychology, 55 (4), 625-633.

22. Ybrant, H. (2008). The relation between self concept and social functioning in adolescence. Journal of Adolescence, 31 (1), 1-16. 